\title{
Do Business Incubators Function as a Transfer Technology Mechanism from University to Industry? Evidence from Portugal
}

\author{
João Paulo Coelho Marques ${ }^{*}, 1$, J.M.G. Caraça ${ }^{2}$ and H. Diz ${ }^{3}$ \\ ${ }^{I}$ ISCAC-Coimbra Higher Institute of Accounting and Administration, Quinta Agricola-Bencanta 3040-316 COIMBRA, \\ Portugal \\ ${ }^{2}$ Calouste Gulbenkian foundation, Av. de Berna, 45-A 1067-001 LISBON, Portugal \\ ${ }^{3}$ DEGEI-Department of Economics, Management and Industrial Engineering, University of Aveiro, 3810-193 Aveiro \\ Portugal
}

\begin{abstract}
This paper concerns an empirical study on the university-industry cooperation, with the motivation that incubators would function as a transfer technology mechanism. It describes the links relating to R\&D, human resources and provision of services for a sample of 79 firms based in the 11 incubators and universities. The results confirm some factors that affect the strength of such links-size of firms, R\&D activities and economic sector, and revealed two other factors-incubators' statutory situation and firm origin. It also emerges that while the university stake in the incubators' capital is quite small, and the involvement of firms in R\&D activities is rare, there is a significant formal involvement with the society following a global trend towards "entrepreneurial university". This suggests that the university contribution to the development of firms' activities is more related to providing information that complements their technological endeavours, and less to creating innovations, ready for market.
\end{abstract}

Keywords: University-industry cooperation, business incubators, entrepreneurial university, knowledge/technology transfer, Portugal.

\section{INTRODUCTION}

It is nowadays recognised that the standard of living of a nation depends on developing science and technology. Significant progress worldwide in the new micro-electronic technologies and computers, for example, has led to advances in all areas of human activity, in social, economic and in particular entrepreneurial terms. The high rate of technological change inspired by competition between industries on an international level has forced most firms to turn their attention to technological matters as factors that can enhance productivity. This competitive dynamic has defined and driven the rapid and widespread pace of innovation.

Therefore, the ability of businesses to engage with innovation and development is generally recognised as being the driving force behind increased revenue and improved living standards. Small innovative firms, including the new technology-based firms, are decisive actors in this process, since they accelerate structural change and create new forms of employment to replace those that have been lost due to the decline of the older industries or the declining status of the larger firms. In this context, the "business incubator" institution plays an important role, to support and increase this dynamic trend, as a knowledge/technology transfer mechanism.

*Address correspondence to this author at the ISCAC-Coimbra Higher Institute of Accounting and Administration, Quinta Agrícola-Bencanta 3040-316 COIMBRA, Portugal; Tel: +351-239 802 000; Fax: +351-239 445 445; E-mail: jmarques@iscac.pt
This study concerns the relations between two distinct social agents whose goals, results and social recognitions are completely different: universities and industry. It examines university-industry (U-I) interaction in the context of business incubators, with the expectation that this knowledge/technology transfer mechanism both facilitates and fortifies these relations. It is therefore the major purpose and motivation of this paper to develop an exploratory study on business incubators about the U-I cooperation, complementing the existing studies about this relation and in order to overcome some of the existing gaps in literature.

The research is based on a study of Portuguese business incubators linked with University, and considers the construction, fulfilment and intersection of three taxonomies that underpinned its modelling: characteristics of the incubators; characteristics of the businesses, and U-I links. The study involved 11 Portuguese incubators promoted by and/or associated with universities. It was possible to learn about and assess the kinds of cooperation links in a sample of 79 firms in incubation and the respective universities. More specifically, this study concerns the firm-university relationship in terms of $\mathrm{R} \& \mathrm{D}$, and the expectation that incubators operate as a transfer technology mechanism that dynamizes U-I cooperation and boosts joint R\&D. This work therefore describes the R\&D, human resources and service provision links between firms based in incubators and the promoting and/or associated universities. It assesses the intensity of cooperation links, their results, effects, benefits and importance to the development of the partners' activities, and it explores the factors that affect the intensity of relations. This last aspect is analyzed by observing the 
importance of certain general characteristics of the incubators, and certain general characteristics of the firms based in them. The importance of each of these characteristics to the determination of cooperation links with the university is also examined.

This study approaches four sets of research questions related to the knowledge on: 1-U-I cooperation links between business being incubated and the promoting and/or associated universities and the intensity of their links; 2Ways of knowledge/technology transfer, their results, effects and benefits; 3-Firms and incubator characteristics which affect the existence of links; and 4-Relations between firms characteristics and those of incubators.

The work is organized in 6 Sections. After the Introduction included in section 1, Section 2 gives a brief literature review of U-I cooperation and business incubators. Section 3 covers the methodology used to design the empirical study and explains the research questions. Section 4 describes the Portuguese situation and the sample of firms. The results and discussion of the empirical data are given in Section 5, according to the replies to the research questions. Finally, Section 6 presents the main conclusions and develops some policy implications which tend to increase knowledge/technology transfer.

\section{BRIEF LITERATURE REVIEW}

\subsection{University-Industry Cooperation}

The present University-industry (U-I) cooperation picture takes place in the context of the National System of Innovation [1, 2] being widely studied in this scope. But implementing this concept to correspond to the results anticipated for both the universities and for industry is still a major challenge.

Among the studies on U-I cooperation links, we emphasize the works of Freeman [3], Geisler and Rubenstein [4], Hall et al. [5], Lööf and Broström [6], Marques and Caraça [7], Santoro and Gopalakrishnan [8], Schartinger et al. [9], Siegel et al. [10] and Vedovelho [11, 12] among many others. Most of these works analyse the U-I interaction in several contexts such as Science and Technology (S\&T) Parks, Universities, R\&D Institutions, Technology Transfer Office, firms and several government organisations. However, none of them focus research on business and/or technology incubators.

The analysis of these studies, allows us to observe that such present trends are for government-sponsored R\&D programmes to decline, for businesses to cut costs, for information and communication technology to forge ahead. These, and various global factors, have focused the attention of major researchers, managers and politicians on the need to strengthen relations between universities and industry so as to create greater synergies, both scientific and technical, to try and produce mutually beneficial results. The implicit basis of this reasoning is that universities are repositories and generators of experience and scientific knowledge. They can use interlinked mechanisms to transfer at least some of their stock of knowledge to firms.

So there are powerful reasons for firms and universities to join forces. The firm benefits by having access to highly trained human resources, advanced equipment and installations in the universities, and its image is enhanced by collaboration with an outstanding academic institution [6]. The universities, meanwhile, interact with industry to acquire additional funding, particularly for research. They also want to expose their students and lecturers to practical problems, create job opportunities for graduates, and gain access to areas of applied technology and new research issues. But universities and industry differ enormously in institutional terms, in their organization, their values, tolerance, levels of quality and, indeed, social objectives. They depart from different conceptual platforms, and diverge in terms of accumulated tradition, the behaviour of their personnel in relation to the near and more distant future, and institutional planning. Comparing the organizations, we find a large number of different ideas which could, at first sight, lead to conflict. But the need for conciliation and cooperation between these institutional partners has long been recognized, motivated and encouraged $[13,14]$.

Therefore in view of the contemporary nature of U-I relations and of the evolution of roles traditionally given to the university-to educate, research and develop economically and socially the region, new institutional frameworks have emerged relating to innovation as it is the case of the Triple helix model of university-industry-government relations [15]. This model gives the university an entrepreneurial role in its region $[16,17]$ where some collaborative activities have been instrumental in helping firms in advancing and propagating new technologies in many economic sectors.

However, for all its importance, U-I cooperation has made only a modest, limited contribution to the innovative activity of firms and the search for technical solutions. In fact, universities have been more important to firms by developing their traditional activities-training staff and increasing scientific and technical knowledge through independent research-than by applying and exploiting its results commercially in industry [18-23]. This is particularly important because contact between people facilitates the tacit transfer of technology, which is the kind of information that comes more from experience than instruction, and this is fundamental to innovation.

Several authors mentioned above, have assessed the strength of U-I cooperation. Other empirical studies seem to suggest that firms with more employees [24-27] and stronger $\mathrm{R} \& \mathrm{D}$ activities [3, 20, 28], engaged in high technology economic sectors $[18,19]$ are more inclined to create links with a university than other firms. But this generalization should be made with caution. This because we found only the empirical study of Vedovelho $[11,12]$ that analyses these three characteristics of firms together within a Science Park context. Furthermore, the geographic proximity of firms and universities does not seem to be a determining factor in the creation of links between them. Thus the knowledge of these and of other determining factors in the U-I cooperation have risen a certain scientific curiosity in knowing how that interaction is made within business incubators.

\subsection{Business Incubators}

Within today's economic reality and knowledge-based society, universities, in spite of their traditional mission of education and research, are steadily assuming new roles, including that of entrepreneur. This function has thus 
become the new defining feature of the new university and of its new mission of economic and social development. Business incubation is the mechanism and infrastructure that is tending to be used to support the generation of new firms, commercialize technology and attract investment $[17,29]$.

Regarding the business incubator as a mechanism for transferring knowledge/technology [30], this has been seen [31-33] as an instrument for technological development, relationship networking, designed to speed the growth and success rate of new ventures by offering a range of services and support resources. One of the main goals of an incubator is to create successful firms that are financially viable and independent, that create jobs, vitalize their neighbourhoods, commercialise significant new technologies and boost local and national economies when they leave the programme. The literature of the speciality often indicates another typology of incubators, namely the "technology incubator", which is different from the "business incubator" itself, due to its emphasis on supporting the technological development stage [34]. In spite of these differences and diversity on types and notions of incubators, in the present study we will keep the concept of "business incubator" as an accommodating notion with the essential characteristics of start-ups nurturing activity, namely the low cost support, to a wide range of businesses not exclusively of technological basis. The study includes also Business Incubators, Technology Incubators, Business Innovation Centers (BIC) and the business incubator as a function of a S\&T Park or Technology Park.

Many studies have been carried out on business incubators in general and technology incubators in particular. Some of them are: Aerts et al. [35], Allen and Bazan [36], Campbell et al. [37], Colombo and Delnastro [38], Jin et al. [39], Lee [40], Matusiak [41], Mian [42], Phillips [43], Sofouli and Vonortas [44], Tornatzky et al. [45] and Wiggins and Gibson [46] among many others. They characterize business incubation, with different objectives, also representing the current state of incubators, both over time and between countries, to give a sounder understanding of the globalization of the concept. Many of the above studies confirm the heterogeneity and multiplicity of purposes represented by the implementation of incubators and similar phenomena, in various countries.

The analysis of the above empirical studies, revealed a few references to the establishment of links with a university. Rothaermel and Thursby [47] focus attention into the technology incubator as university-based technology initiatives that should facilitate knowledge flows from the university to the incubator firms. These researchers investigate the processes of how technology ventures access university knowledge and how does it affect their performance. Recently, Sofouli and Vonortas [44], in a case study of Greece, stress that business incubators appear to have a strong working relationship with a research-intensive university. But, in general, the overall above empirical studies reveal that establishing links between firms based in incubators and universities, has not been assessed until now. Only a few of the studies analysed deal with the importance of the university to technology incubators, to knowledge/technology transfer, the generation of academic spin-offs and the establishment of links with incubator-based start-ups. Most of the links found only relate to informal contacts with academics and the use of university support and infrastructure.

So, in this paper we build on the ideas from the literature reviewed, that there is a pattern, too, of establishing links between incubator-based firms and the promoting universities, which could be influenced by the characteristics of the firms under incubation, such as their size in terms of employees, economic sector, R\&D activities and origin of firms. The characteristic of incubators as a statutory situation could also influence the establishment of U-I links. Most incubators have hosted firms that could generally be classified as New Technology-Based Firms. These are micro and small firms in high technology sectors, like information and communication technologies and biotechnology. More important, because of their small size, it may be anticipated that the level of R\&D activities developed in firms under incubation would also be low. Their main activities appear to be (with varying degrees of technological sophistication) in design, development and consultancy, and not in R\&D.

Despite these trends, the evidence from the literature with reference to university incubators and the commercialization of technology [45, 48-50] shows that this cannot be the natural panorama, typical of firms in incubation. The commercialization of knowledge/technology by setting up new firms is an ideal role for university-promoted incubators, but not the only one. However, many important questions related to U-I interaction and business incubators have been neglected in these studies. One is the lack of more systematic research into the characteristics of incubators and the firms based in them, and their potential influence on the creation of links between universities and industry, especially those related to $R \& D$ and the promoting or sponsoring university. Nor has the university's role as promoter of an incubator and manager of intellectual property, i.e. the internal management of publishing or patenting, yet been assessed. Furthermore, the scarcity of data on the university part in the U-I relation makes it impossible to accurately assess the U-I links established through business incubators. The analysis of these topics and those related to the pattern of establishment of U-I links, like intensity, benefits, effects and results for firms and universities, will broaden our understanding of the links between start-ups under incubation and universities.

\section{METHODOLOGY AND DESIGN}

The research is exploratory: it does not try to test hypotheses but aims to respond to a series of research questions related to the goals defined, which are:

1. What cooperation links are established between the firms based in the various incubators and their associated and/or promoting universities? How intense/frequent are they?

2. How is the knowledge/technology resulting from the cooperation transferred? What are the final results, effects and benefits of these links?

3. What are the characteristics of the firms and the incubators that affect the existence of links with promoting and/or associated universities?

4. What characteristics of the sample firms are related to the characteristics of these incubators? 
This present study initially included 20 incubators that were analysed in terms of "being associated with and/or promoted by a university". A group of Incubators was thus established and these were subsequently analysed according to three additional criteria:

- They were real, physical business incubators, not virtual or non-physical ones;

- $\quad$ Regardless of their legal status, they did not operate on a profit-making basis;

- $\quad$ They were currently operating.

After applying these filters, we were left with a group of 11 incubators.

Starting with a group of 160 companies based in the 11 incubators, we then selected a sample of businesses to study individually. This selection was based on the research goals and the size of the various populations. A sample was drawn from all the incubators with more than 8 firms based in them, to study what was considered to be a reasonable number (a portion of 0.33 or approximately $33 \%$ ), bearing in mind the varying number of firms in each incubator. A stratified sample was used, consisting of two strata: year incubation began and sector of economic activity. A weighting criterion was added, which involved selecting at least one company from each stratum. In the incubators with 8 or more firms, we aimed to interview all $(100 \%)$ of them, with a sampling error $=2.419 \%$ being found.

The modeling of the research takes into account the necessary comprehension of the context of incubators and the deepening of U-I cooperation in those incubators with links to a university. The structuring process is based on the construction, fulfilment and intersection of three taxonomies: characteristics of the incubators, characteristics of the businesses, and U-I links. The taxonomy of characteristics of business incubator includes seven characteristics: 1-Start-up date; 2-Incubator legal form; 3-Statutory situation/dependence of Incubator; 4-Shareholding of university in incubator capital (percentage); 5-Sector; 6Funding sources; and 7-Services provided. The taxonomy of the business includes nine characteristics: 1-Firm origin; 2Sector of economic activity; 3-Time in incubation; 4-Legal status of firm; 5-Firm size (number of employees); 6-Main activity; 7-Existence of R\&D activity; 8-Type of R\&D activity; and 9-Intensity of R\&D activity (number of employees) (only full-time R\&D firms). Finally, the taxonomy of U-I links, includes fifteen types divided in: A) R\&D and Human Resources Links: 1-R\&D contracts; 2R\&D projects of university-sponsored firms; 3-Firms' access to university $\mathrm{R} \& \mathrm{D}$ agenda; 4-University personnel allotted full-time to firms; 5-Lecturers and researchers as part-time consultants for firms; 6-Informal contacts with academics; 7Recruitment of new university graduates; 8-Support for student projects; 9-Training given by university to firm's employees; and 10-Other links; B) Service Provision links: 1-Firms' access to university information and informatics services; 2-Firms' access to university equipment and laboratory facilities; 3-University laboratory analyses, design, tests and assessments; 4-Firm as supplier of university goods/service; and 5-Other links.
The main results of the research stemmed from three "Interview Scripts" given to: 1-the directors of the 11 incubators; 2-managers of the 79 firms in the sample; and 3the people responsible for defining U-I cooperation policy and strategies in the 8 promoting and/or associated universities.

The field work was done between February and July 2004. Personal interviews were conducted, using previouslyprepared scripts designed to find out about the different aspects of the taxonomies used. The incubator script asked about their seven characteristics, incubation dynamics, structure and services provided to firms (Appendix A). The firms' script was designed to learn about their nine characteristics, and fifteen U-I links and reasons for joining the incubator, among others (Appendix B). The third script was used in the 8 Universities involved in the 11 incubators with the aim of finding out about the guidelines, strategies and policies of each University in its involvement in incubation activities (Appendix C). Along with this, we used information supplied by the incubators, their promoters and the firms we interviewed. This information included prospectuses, business and financial reports, statutes and articles on business incubators in specialist journals and books and general press articles.

Whenever possible, both qualitative and quantitative analytical techniques and methods were used to process the information. Qualitative processing used classic methods, especially "content analysis" and the "analysis of taxonomies". Qualitative data were used to understand and justify the quantitative results obtained as well as to express the policy implications.

Quantitative processing was based on simple and cross tabulation of data and the application of non-parametric statistical tests, viz. the independence test and the exact Chi Square test, to the simple choice nominal and numerical variables, and the Chi Square adjustment test to the multiple choice nominal and numerical variables. Whenever possible, Cramer's V coefficient was used to measure and quantify the association.

\section{PORTUGUESE BUSINESS INCUBATORS}

The analysis of the 11 incubators confirmed that Portuguese business incubators are not isolated organisations. They tend to be linked, in one way or another, to state and private sources of scientific and/or technological knowledge, including the 8 universities involved, S\&T parks, Technology parks, BICs and state and private R\&D institutions, as well as technology-based firms and sources of funding. The commonest type of promoting body for the incubators we studied were BICs, with 4 incubators (3 BICs and 1 incubator/BIC based in a Technology Park) or $36.4 \%$ of the total, meaning that, even though they are innovation centres within a European innovation and enterprise network, the importance of incentives from government entities, their funding and support, are additional factors promoting incubators.

University involvement in the incubators is varied in terms of percentage shareholding in an incubator's capital. Even though this involvement is largely low-level, and actual involvement in the firms' $R \& D$ activities scarce, the current situation represents a significant effort by Portuguese 
Table 1. Summary of Incubator Characteristics (Taxonomy) $(\mathrm{N}=11)$

\begin{tabular}{|l|l|l|l|l|}
\hline $\begin{array}{c}\text { C1-Start-Up } \\
\text { Date }\end{array}$ & \multicolumn{1}{|c|}{$\begin{array}{c}\text { C2-Legal form of } \\
\text { Incubator }\end{array}$} & $\begin{array}{c}\text { C3-Statutory Situation/ } \\
\text { Dependence of Incubator }\end{array}$ & $\begin{array}{c}\text { C4-Shareholding of University in } \\
\text { Incubator Capital (N=10) })^{\mathbf{a}}\end{array}$ & C5-Sector Orientation $^{\mathbf{b}}$ \\
\hline \hline $2(1980 \mathrm{~s})$ & $\begin{array}{l}4 \text { (Private non-profit } \\
\text { making institution }\end{array}$ & 3 (University incubator) & $6(<30 \%)$ & 5 (No sector) \\
\hline $6(1990 \mathrm{~s})$ & $\begin{array}{l}1 \text { (Private limited } \\
\text { company) }\end{array}$ & $\begin{array}{l}\text { 2 (Incubator incorporated } \\
\text { within a S\&T Park }\end{array}$ & $2(30-65 \%)$ & 6 (With sector): \\
\hline $3(2000$ and after) & $\begin{array}{l}5 \text { (Public limited } \\
\text { company) }\end{array}$ & $\begin{array}{l}1 \text { (Incubator incorporated } \\
\text { within a Technology Park }\end{array}$ & $2(>65 \%)$ & $\begin{array}{l}2 \text { (Service enterprise } \\
\text { incubator) }\end{array}$ \\
\hline & 1 (other) & $\begin{array}{l}1 \text { (Incubator based in a } \\
\text { Technology Park) }\end{array}$ & $\begin{array}{l}6 \text { (Tech. based business } \\
\text { incubator) }\end{array}$ \\
\hline & & $\begin{array}{l}3 \text { (Business innovation } \\
\text { centres-BICs) }\end{array}$ & 1 (Other) \\
\hline
\end{tabular}

Notes:

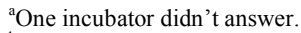

${ }^{\mathrm{b}}$ The option of sector orientation defined in the statutes (memorandum and articles of association) is a multiple choice option, so each incubator can have more than one sectorial orientation. These items should be read horizontally.

Table 2. Summary of Sources of Funding and Services Provided by Incubators (Taxonomy) (N=11)

\begin{tabular}{|c|c|c|c|c|}
\hline \multirow{2}{*}{ C6-Funding Sources ${ }^{\mathrm{a}}$} & \multicolumn{4}{|c|}{ C7-Services Provided ${ }^{\mathrm{a}}$} \\
\hline & Basic Services & Technical Services & Management Services & Strategic Services \\
\hline 8 (Rent income) & $\begin{array}{l}11 \text { (Physical } \\
\text { infrastructures) }\end{array}$ & 8 (Access to University R\&D) & 6 (Accounting/Financial) & $\begin{array}{l}9 \text { (Access to information on } \\
\text { funding sources) }\end{array}$ \\
\hline $\begin{array}{l}10 \text { (Income from services } \\
\text { rendered) }\end{array}$ & 10 (Cleaning) & 10 (Technical consultancy) & 6 (General management) & 10 (Access to legislation) \\
\hline $\begin{array}{l}0 \text { ("Business Angels" } \\
\text { investments) }\end{array}$ & 11 (Telecoms) & 1 (Other technical services) & 8 (Sales/Marketing) & $\begin{array}{l}9 \text { (Support in bank } \\
\text { negotiations) }\end{array}$ \\
\hline 1 (Venture capital) & $\begin{array}{l}5 \text { (Other basic } \\
\text { services) }\end{array}$ & & 1 (Other management services) & $\begin{array}{l}5 \text { (Technical training of } \\
\text { Human Resources) }\end{array}$ \\
\hline 5 (Community funding) & & & & $\begin{array}{l}8 \text { (Support in institutional } \\
\text { relations and agreements } \\
\text { between firms) }\end{array}$ \\
\hline 1 (University funding) & & & & 2 (Other strategic services) \\
\hline $\begin{array}{l}3 \text { (Local, regional and } \\
\text { central government } \\
\text { grants) }\end{array}$ & & & & \\
\hline 5 (Other forms of funding) & & & & \\
\hline
\end{tabular}

${ }^{\mathrm{a}}$ Multiple choice response.

universities to open up more to society. A great deal of progress has been made in the past 15 years, at least from the point of view of formal institutional involvement with the community. The 8 universities taking part showed increasing interest in fully assuming their entrepreneurial role, regardless of constraints arising from the public status of 7 of them. Tables 1 and 2 list the characteristics of the 11 incubators.

The characteristics of the sample firms' and R\&D activities (Tables 3 and $\mathbf{4}$ ) confirmed previous studies in this area. The most technologically sophisticated economic sectors predominated, including ICTs (48.1\%) and Biotechnology and Health $(8.9 \%)$, which thus dominated incubator occupation, with $57 \%$ of firms. Firm size also confirmed the previously-observed trend, with $88.6 \%$ of firms employing fewer than 10 workers, demonstrating that firms under incubation are basically micro and small startups. Incubators have very few university spin-offs, because only 7 firms $(8.9 \%)$ were this type of firm. This is contrary to the widely spread idea that university involvement in incubation activities would represent adequate organizations that could promote and establish small businesses originated by $R \& D$ outcomes. This research failed to confirm such ideas.

The development of R\&D activities was by no means a priority for the firms in the sample, because only $51.9 \%$ of the firms in the sample said it was their main activity, with only 1 firm (1.8\%) involved in basic research and 18 $(32.7 \%)$ in applied research, thus limiting the possibilities of interacting with the universities. It appeared, too, that the 
Table 3. Summary of Sample Firms' Characteristics (Taxonomy) (N=79)

\begin{tabular}{|l|l|l|l|l|}
\hline \multicolumn{1}{|c|}{ C1-Firm Origin } & \multicolumn{1}{|c|}{ C2-Sector of Economic Activity a } & \multicolumn{1}{|c|}{ C3-Time in Incubation } & $\begin{array}{c}\text { C4-Legal Status } \\
\text { of Firm }\end{array}$ & \multicolumn{1}{|c|}{$\begin{array}{c}\text { C5-Firm Size (No. } \\
\text { Employees in Firm) }\end{array}$} \\
\hline \hline $8.9 \%$ (University spin-off firms) & $\begin{array}{l}48.1 \% \text { (Information and } \\
\text { Communications Technology) }\end{array}$ & $39.2 \%$ (Less than 1 year) & $\begin{array}{l}91.1 \% \text { (Private } \\
\text { limited company) }\end{array}$ & $39.2 \%$ (Up to 3) \\
\hline $7.6 \%$ (Other firms' spin-offs) & $8.9 \%$ (Biotechnology and Health) & $27.8 \%(1$ to 2 years) & $\begin{array}{l}7.6 \% \text { (Public } \\
\text { limited company) }\end{array}$ & $49.4 \%(4$ to 10$)$ \\
\hline $81.0 \%$ (New firm) & $43.0 \%$ (Other sectors) & $11.4 \%(2$ to 3 years) & $1.3 \%$ (Other) & $5.1 \%(11$ to 15$)$ \\
\hline $1.3 \%$ (Already existing firm) & & $21.5 \%$ (More than 3 years) & & $3.8 \%(16$ to 25$)$ \\
\hline $\begin{array}{l}1.3 \% \text { (Subsidiary of already } \\
\text { existing firm) }\end{array}$ & & & & $1.3 \%(26$ to 50$)$ \\
\cline { 2 - 5 } & & & $1.3 \%$ (More than 50) \\
\hline
\end{tabular}

Note:

"The "Information and Communications Technology" (ICT) sector includes: 1-Communications; 2-Computer hardware; 3-Computer software, and 4-Electronics. The "Biotechnology and Health" sector includes: 5-Medical and health care products and services. and 6-Genetic engineering and molecular biology. The third group, "Other sectors" includes: 7-Energy; 8-Consumer products; 9-Industrial products, and 10-Other sectors.

Table 4. Summary of Sample Firms' R\&D Activities (Taxonomy)

\begin{tabular}{|c|c|c|c|}
\hline C6-Main Activity ${ }^{a}(\mathrm{~N}=79)$ & C7-R\&D Activities $(\mathrm{N}=79)$ & C8-Type of R\&D Activity ${ }^{\mathrm{a}}(\mathrm{N}=55)$ & $\begin{array}{c}\text { C9-Intensity of R\&D } \\
\text { Activity }^{\mathbf{b}}(\mathbf{N}=7)\end{array}$ \\
\hline $51.9 \%(\mathrm{R} \& \mathrm{D})$ & $30.4 \%$ (No R\&D) & $1.8 \%$ (Basic research) & $42.9 \%$ (Up to 2$)$ \\
\hline $40.5 \%$ (Software development) & $8.9 \%$ (Full-time R\&D) & $32.7 \%$ (Applied research) & $42.9 \%(3$ to 5$)$ \\
\hline $1.3 \%$ (Hardware development) & $60.8 \%$ (Part-time R\&D) & Experimental development in: & $14.3 \%(10$ and over $)$ \\
\hline $11.4 \%$ (Prototype design and construction) & & $60.0 \%$ (New prod. development) & \\
\hline $43.0 \%$ (Consultancy) & & $40.0 \%$ (Improving existing products) & \\
\hline $3.8 \%$ (Testing and laboratory analysis) & & $38.2 \%$ (Improving existing processes) & \\
\hline $10.1 \%$ (Sales and distribution) & & $3.6 \%$ (New administrative techniques) & \\
\hline $44.3 \%$ (Other) & & $1.8 \%$ (Other) & \\
\hline
\end{tabular}

${ }^{\mathrm{a}}$ Characteristics C6 and C8 are multiple choice.

${ }^{\mathrm{b}}$ Only full-time R\&D firms.

managers of the incubators had not yet woken up to the advantages of increasing the promotion of U-I cooperation links, since very little time was spent on this task, on the whole. Furthermore, the main reasons for firms' location in incubators were related to space, prestige and image, rather than to other factors that it was naturally felt would have greater influence, such as developing R\&D links with the university. This was only indicated by 20 firms $(25.3 \%$ of the sample) (Appendix D).

\section{RESULTS AND DISCUSSION}

\subsection{Question 1: Cooperation Links and their Intensity}

Table 5 gives the aggregate pattern of U-I links found, with a breakdown of the taxonomy of these links, subdivided into $\mathrm{R} \& \mathrm{D}$ and human resources links and provision of services links. The aim was to answer the first research question. This study therefore focused on presenting the taxonomy of the links found, discussing the results in terms of the number of links and their intensity, for the 46 firms in the sample which had U-I links.
The first major task was to find the true proportions of firms with and without links. It was found that 46 micro and small enterprises under incubation had some kind of links with a university, representing $58.2 \%$ of the total. The confidence interval of the true proportion of firms having cooperation links with universities was, for this value, $47.4 \%$ and $69.1 \%$. The lower limit was taken for this purpose, being a small value, bearing in mind that all the incubators are promoted by and/or associated with universities, and that 3 $(27.3 \%)$ said they actually belonged to an academic institution.

It was observed that the aggregate pattern of cooperation links found concerned "informal contacts with academics", the "recruiting of recent university graduates" and "support for student projects", for, respectively, 91.3\%, 50\% and $39.1 \%$ of the firms indicating links. These results highlight the significance of links based on human resources and the informal transfer of knowledge/technology, relative to the more formal links, based on $R \& D$, such as "R\&D contracts between the parties" mentioned by $19.6 \%$ of firms. Equally relevant is the confirmation that these informal university 
Table 5. Cooperation Links and their Intensity (Taxonomy)

\begin{tabular}{|c|c|c|c|c|c|c|c|}
\hline \multirow{2}{*}{$\begin{array}{c}\text { R\&D and Human } \\
\text { Resources Links }(\mathrm{N}=46)\end{array}$} & \multicolumn{3}{|c|}{ Intensity $^{\mathrm{ab}}(\%)$} & \multirow{2}{*}{$\begin{array}{l}\text { Provision of Services Links } \\
(\mathbf{N}=46)\end{array}$} & \multicolumn{3}{|c|}{ Intensity $\left.{ }^{\mathrm{a}} \mathrm{(} \%\right)$} \\
\hline & High & Medium & Low & & High & Medium & Low \\
\hline $19.6 \%$ (R\&D contracts) & 11.1 & 22.2 & 66.7 & $\begin{array}{l}30.4 \% \text { (Firms' access to university } \\
\text { information and informatics } \\
\text { services) }\end{array}$ & 42.9 & 28.6 & 28.6 \\
\hline $\begin{array}{l}8.7 \%(\mathrm{R} \& \mathrm{D} \text { projects of } \\
\text { university-sponsored firms) }\end{array}$ & 25.0 & 25.0 & 50.0 & $\begin{array}{l}26.1 \% \text { (Firms' access to university } \\
\text { equipment and laboratory facilities) }\end{array}$ & 25.0 & 8.3 & 66.7 \\
\hline $\begin{array}{l}28.3 \% \text { (Firms' access to } \\
\text { university R\&D agenda) }\end{array}$ & 23.1 & 53.8 & 23.1 & $\begin{array}{l}8.7 \% \text { (University laboratory } \\
\text { analyses, design, tests and } \\
\text { assessments) }\end{array}$ & 75.0 & 25.0 & 0.0 \\
\hline $\begin{array}{l}6.5 \% \text { (University personnel } \\
\text { allotted full-time to firms) }\end{array}$ & 66.7 & 33.3 & 0.0 & $\begin{array}{l}\text { 39.1\% (Firm as supplier of } \\
\text { university goods/services) }\end{array}$ & 27.8 & 27.8 & 44.4 \\
\hline $\begin{array}{l}30.4 \% \text { (Lecturers and } \\
\text { researchers as part-time } \\
\text { consultants for firms) }\end{array}$ & 42.9 & 35.7 & 21.4 & $\begin{array}{l}6.5 \% \text { (Other provision of services } \\
\text { links) }\end{array}$ & 66.7 & 33.3 & 0.0 \\
\hline $\begin{array}{l}91.3 \% \text { (Informal contacts } \\
\text { with academics) }\end{array}$ & 40.5 & 35.7 & 23.8 & & & & \\
\hline $\begin{array}{l}50.0 \% \text { (Recruitment of new } \\
\text { university graduates) }\end{array}$ & 17.4 & 4.3 & 78.3 & & & & \\
\hline $\begin{array}{l}39.1 \% \text { (Support for student } \\
\text { projects) }\end{array}$ & 33.3 & 16.7 & 50.0 & & & & \\
\hline $\begin{array}{l}10.9 \% \text { (Training given by } \\
\text { university to firm's } \\
\text { employees) }\end{array}$ & 0.0 & 20.0 & 80.0 & & & & \\
\hline $\begin{array}{l}15.2 \% \text { (Other R\&D and HR } \\
\text { links) }\end{array}$ & 28.6 & 28.6 & 42.9 & & & & \\
\hline
\end{tabular}

${ }^{a}$ High frequency (1 or more links/week), medium frequency (1 link/month), low frequency (3-links/year or less).

${ }^{b}$ Percentage relating to intensity of cooperation links are calculated for the number of firms indicating each type of link.

contacts are predominantly medium and high intensity, and R\&D contracts are mostly low intensity. These findings suggest that the low level of informality and poor organizational capacity of a link helps to increase the intensity with which they occur, while links which, by their nature, require organizational skills and some degree of formality and structuring, tend to occur with less intensity.

Also interesting were the findings regarding the reasons for 33 sample firms $(41.8 \%)$ having no links. The main explanations are "lack of opportunity" to establish cooperation links with a university, and "the issue never came up", offered by 23 and 16 firms, respectively (Appendix D). These reasons suggest that most firms are illinformed and so do not think about the opportunities for U-I cooperation, or about how university departments and laboratories could be opened up to them. In fact, if the university authorities intervened with each firm, this could also help to reduce the frequency of these and other excuses, such as "the university is not interested in our project", mentioned by 5 firms.

\subsection{Question 2: Knowledge/Technology Transfer Through U-I Links}

In this section we analysed the forms of knowledge/technology transfer, benefits, effects and final results of the links, for the 46 firms in the sample which had U-I links (Table 6). Knowledge/technology was mostly transferred (in the cooperation links studied) by "simple transfer", in which informal contacts with academics were very important. It was also interesting to see that the main final results from this group of links were related to "advice and technical consultancy (written and non-written)" and "product and/or process innovation". The study of the main practical effects of U-I links was also important. It was found that the three areas in which knowledge/technology transfer took place were "human resources training", "meeting customer's needs" and "improving company efficiency". In the context of the benefits of cooperation, $78.3 \%$ of firms said the main benefits were "the possibility of acquiring know-how and scientific knowledge and technical expertise", and for $45.7 \%$ of firms the main benefit of the universities was the "possibility of applying knowledge in organizations". Quite interesting is the finding that the benefit of obtaining R\&D funding is the one least achieved.

\subsection{Question 3: Determining Factors of Existing U-I Links}

All incubator and firms characteristics were crossexamined according to the existence or not of U-I links. A confidence degree of $90 \%$ was found for the results obtained.

The results of the analysis (Table 7) are given below.

1. The only incubator characteristic that affects the existence of cooperation links with the universities is 
Table 6. Transfer of Knowledge/Technology via U-I Links (N=46)

\begin{tabular}{|l|l|l|l|l|}
\hline Forms of Transfer & \multicolumn{1}{|c|}{ Benefits to Firms } & \multicolumn{1}{|c|}{ Benefits to University } & \multicolumn{1}{|c|}{ Final Results of Transfers } & \multicolumn{1}{c|}{ Effects of Transfers } \\
\hline \hline $\begin{array}{l}2.2 \% \text { (Licence } \\
\text { agreement after } \\
\text { patent registration) }\end{array}$ & $\begin{array}{l}78.3 \% \text { (Chance of acquiring know- } \\
\text { how, scientific knowledge, technical } \\
\text { expertise) }\end{array}$ & $\begin{array}{l}32.6 \% \text { (Chance of applied } \\
\text { research projects) }\end{array}$ & $\begin{array}{l}45.7 \% \text { (Product and/or process } \\
\text { innovation) }\end{array}$ & $\begin{array}{l}23.9 \% \text { (Improved } \\
\text { profitability of firm) }\end{array}$ \\
\hline $\begin{array}{l}6.5 \% \text { (License } \\
\text { agreement) }\end{array}$ & $\begin{array}{l}28.3 \% \text { (Low-cost access to } \\
\text { technology) }\end{array}$ & $\begin{array}{l}45.7 \% \text { (Chance of applying } \\
\text { scientific knowledge in } \\
\text { orgs) }\end{array}$ & $\begin{array}{l}26.1 \% \text { (Improving existing } \\
\text { products and/or processes) }\end{array}$ & $\begin{array}{l}17.4 \% \text { (Increased } \\
\text { market share) }\end{array}$ \\
\hline $\begin{array}{l}19.6 \% \\
\text { Acquisition/sales) }\end{array}$ & $\begin{array}{l}15.2 \% \text { (Means of obtaining third } \\
\text { party funding for research) }\end{array}$ & $\begin{array}{l}17.4 \% \text { (Means of obtaining } \\
\text { R\&D funding) }\end{array}$ & $\begin{array}{l}17.4 \% \text { (Building prototypes of } \\
\text { new goods or equipment) }\end{array}$ & $\begin{array}{l}26.1 \% \text { (Increased } \\
\text { productivity) }\end{array}$ \\
\hline $\begin{array}{l}87.0 \% \text { (Simple } \\
\text { transfer) }\end{array}$ & $\begin{array}{l}47.8 \% \text { (Benefiting from university } \\
\text { credibility and R\&D experience) }\end{array}$ & $\begin{array}{l}41.3 \% \text { (Practical training } \\
\text { of human resources) }\end{array}$ & $\begin{array}{l}34.8 \% \text { (Training of human } \\
\text { resources) }\end{array}$ & $\begin{array}{l}28.3 \% \text { (Improved } \\
\text { efficiency of firm) }\end{array}$ \\
\hline $\begin{array}{l}4.3 \% \text { (Other forms } \\
\text { of transfer) }\end{array}$ & $\begin{array}{l}21.7 \% \text { Continuous technological } \\
\text { updating) }\end{array}$ & $41.3 \%$ (Other benefits) & $\begin{array}{l}87.0 \% \text { (Written and non- } \\
\text { written advice and technical } \\
\text { consultancy) }\end{array}$ & $\begin{array}{l}37.0 \% \text { (Meeting } \\
\text { customers' needs) }\end{array}$ \\
\hline & $47.8 \%$ (Training of human resources) & & $10.9 \%$ (Other results) & $\begin{array}{l}56.5 \%(Q u a l i f y i n g \\
\text { human resources) }\end{array}$ \\
\hline
\end{tabular}

the statutory situation/dependence of the incubator, and those responsible for the association, firms with cooperation links and based in a university's incubator. The degree of association found is moderate, but never zero ( $\mathrm{p}$-value $=0.055)$. This association is largely explained by the proximity between the university and its incubator, which quite naturally provides an environment that favours the UI relationship.

2. A firm's characteristics that influenced the existence of U-I cooperation links are: its origin, the economic sector it operates in, number of employees/size and R\&D activities. But the degree of each association varies among them, as follows:

i. a firm's origin determines the existence of cooperation links, and those responsible for the association are the university's spin-off firms, which all of them have natural cooperation links, Even so, this association is weak, and there may be no p-value associated with Cramer's V coefficient, if its value is greater than 0.1 .

ii. A firm's sector of economic activity determines links with a university, with the main source of dependence being Biotechnology firms, which all had links. The degree of dependence is low, but is always there $(p$-value $=0.033)$. One explanation may be that, in this high technology sector, the concentrated nature of the research needs a close link to the sources of knowledge.

iii. The number of employees/firm size also affects the existence of U-I links, with the source of dependence being firms with more than 15 employees. This association showed a strong degree of dependence for Cramer's V coefficient and is always present, as the pvalue is other than zero. The most natural reason for this association is related to the fact that more full-time workers contribute to the creation of more U-I links.

iv. A firm's R\&D activities were found to determine the existence of U-I links, with the source of dependence being simultaneously firms without links and without R\&D activities. The degree of dependence, though low, is always present, as the p-value associated with Cramer's V coefficient is other than zero. One reason for this association stems from the specific nature of $R \& D$ activities, which benefit from interaction with the university.

\subsection{Question 4: Firms Characteristics According to the Incubator Ones}

In this section, the goal was to know how to characterize and position the existing business incubators in Portugal, promoted and/or associated to universities, as well as to know the characteristics of the firms in the sample that are related to the characteristics of the incubators. The results for a confidence degree of $90 \%$ (Tables 8 and 9) are given below:

1. A firm's sector of economic activity is associated with the statutory situation/dependence of the incubator. Analysis of dependence sources revealed 3 origins: First, biotechnology firms based in a university's incubator. Second are firms in the ICT sector which function in an incubator within a technology park, and third are firms operating in Other Sectors, based in BICs. The degree of dependence is moderate, but is always present, as the p-value associated with Cramer's V coefficient is other than zero. The main reason for these findings is that firms in ICT sectors, working mostly in computing, programming, telecommunications and so forth, find conditions ideal for them in incubators based in Technology 
Table 7. Characteristics of Incubators and Firms According to Existence/Absence of U-I Links

\begin{tabular}{|c|c|c|c|c|c|c|}
\hline \multirow{2}{*}{\multicolumn{2}{|c|}{ Characteristics }} & \multicolumn{3}{|c|}{ Test for Independence } & \multicolumn{2}{|c|}{ Cramer's V Coefficient } \\
\hline & & Statistical Value of Test & p-Value ${ }^{a}$ & No. of Firms & Value & p-Value ${ }^{b}$ \\
\hline $\begin{array}{c}\text { Incubator } \\
\text { characteristics }\end{array}$ & Statutory situations & 10.821 & 0.050 & 79 & 0.370 & 0.055 \\
\hline \multirow{4}{*}{ Firm characteristics } & Firm origin & 7.630 & 0.064 & 79 & 0.311 & 0.106 \\
\hline & $\begin{array}{l}\text { Sector of economic } \\
\text { activity }\end{array}$ & 6.848 & 0.032 & 79 & 0.294 & 0.033 \\
\hline & No. employees in firm & 25.005 & 0.0001 & 79 & 0.563 & 0.0001 \\
\hline & $\mathrm{R} \& \mathrm{D}$ activities & 7.211 & 0.023 & 79 & 0.302 & 0.027 \\
\hline
\end{tabular}

Notes:

${ }^{a}$ The null hypothesis to be tested is that the existence/absence of cooperation links is independent of the incubator or firm characteristics.

'The null hypothesis to be tested is that Cramer's V coefficient is equal to zero.

Parks. Firms in the biotechnology sector, on the other hand, naturally find the right atmosphere to nurture them in a university incubator. Finally, companies from other sectors mostly opt to locate in BICs, because these organisations are more open and have no sectoral orientation.

2. A firm's sector of economic activity is also associated with the university's shareholding in the incubator's capital. There is a large number of biotechnology firms based in incubators in which the university has more than $65 \%$ of the capital, the main source of dependence. The statistical tests revealed a moderate association, but it is always present, as the p-value associated with Cramer's V coefficient is other than zero. Such association is justified because universities are interested in biotechnology firms.

3. A firm's sector of economic activity is further associated with incubators' sources of funding, with emphasis for responsibility for the association being on Biotechnology firms in the group of firms from incubators funded by universities. This result is in line with the fact that biotechnology firms are based in university incubators.

4. A firm's size, in terms of its number of employees, is also associated with incubator funding sources, with firms employing 26 to 50 workers, based in incubators financed with venture capital, being mainly responsible for this association. A possible explanation for such association has to do with the fact that to a high number of employees a high number of $\mathrm{R} \& \mathrm{D}$ projects is associated as well as a firm size attracting venture capital.

5. A firm's R\&D activities are also associated with incubator funding sources, with full-time $R \& D$ firms which are based in incubators funded by venture capital being largely responsible for this dependence, again in line with the previous association, showing the natural attraction to venture capital and promising $\mathrm{R} \& \mathrm{D}$ activities.

\section{CONCLUSIONS AND POLICY IMPLICATIONS}

This study focuses on the cooperation links between universities and industry, in the expectation that the incubators operate as a transfer mechanism that dynamizes U-I cooperation and boosts joint R\&D. This article has therefore aimed to provide information that is as detailed as possible, so as to clarify and permit as deep a knowledge as possible of the links forged between micro and small enterprises based in Portuguese incubators, in which a university is an associated and/or promoting entity, and these universities.

A number of limitations influenced the conclusions. First there is the condition of Business incubators, which are a specific, relatively new reality which means that the scale of U-I links for study is restricted. Historic limitations are also important, especially factors relating to Portugal's enterprise structure and the characteristics and dimension of the Portuguese innovation system. The last limiting factor is related to the fact that it was decided to assess U-I links and their benefits to the university and to firms on the basis of the opinion of only one party: the firms. This was due to the high number of incubators and universities involved.

Table 8. Characteristics of Firms According to Incubator Characteristics

\begin{tabular}{|c|c|c|c|c|c|c|}
\hline \multirow{2}{*}{$\begin{array}{c}\text { Firm } \\
\text { Characteristic }\end{array}$} & \multirow{2}{*}{ Incubator Characteristic } & \multicolumn{3}{|c|}{ Test for Independence } & \multicolumn{2}{|c|}{ Cramer's V Coefficient } \\
\hline & & $\begin{array}{c}\text { Statistical } \\
\text { Value of Test }\end{array}$ & p-Value ${ }^{a}$ & No. of Firms & Value & p-Value ${ }^{b}$ \\
\hline \multirow{2}{*}{$\begin{array}{c}\text { Sector of } \\
\text { economic activity }\end{array}$} & Statutory situation/dependence of incubator & 22.159 & 0.013 & 79 & 0.374 & 0.013 \\
\hline & University shareholding in incubator capital & 22.137 & 0.001 & 75 & 0.384 & 0.001 \\
\hline
\end{tabular}

Notes:

${ }^{a}$ The null hypothesis tests the independence of the firm characteristics and the incubators' characteristics.

'The null hypothesis to be tested is that Cramer's V coefficient is equal to zero. 
Table 9. Characteristics of Firms According to Incubator Sources of Funding

\begin{tabular}{|c|c|c|c|c|}
\hline \multirow{2}{*}{ Firm Characteristic } & Funding Sources & \multicolumn{2}{|c|}{ Test for Adjustment } \\
\cline { 3 - 5 } & & Statistical Value of Test & p-Value & No. of Firms \\
\hline \hline Sector of economic activity & Funds from university & 31.58 & $1.0 \mathrm{E}-08^{\mathrm{b}}$ & 5 \\
\hline Firms size/ $\mathbf{N}^{\mathbf{0}}$ employees & Venture capital & 12.005 & 0.035 & 8 \\
\hline R\&D activities & Venture capital & 16.834 & 0.0968 & 8 \\
\hline
\end{tabular}

Notes:

${ }^{a}$ The null hypothesis to be tested is that each funding source is adjusted to the firms' characteristics.

${ }^{\mathrm{b}} 1.0 \mathrm{E}-08=0,0000001$.

The research is exploratory, not trying to test hypotheses but to respond to a series of research questions related to the goals defined. The conclusions arrived at are, however, both clear and interesting. They confirm the initial expectations with regard to considering business incubators an effective and high potential mechanism of technology transfer as far as interactions between the university and the incubating businesses are concerned.

The pattern of U-I links found was heterogeneous which is a result on one hand of the different levels of dynamism and enterprise initiative capacity of the universities promoting and/or associated to incubators, and on the other hand, of the short-term thinking and operation of the firms, with any medium or long term vision being almost completely lacking. As Gibb [51] has shown, technology transfer to SMEs is more often problem-oriented, and is based less on conceptual or fundamental research. The problems involved tend to be specific, not strategic, given the pressure of time that small enterprises have to contend with, and the quickest possible solutions are required. Most links were related to human resources and the informal transfer of knowledge/technology, rather than more formal ones, based on formal R\&D. Equally important is the finding that these informal contacts are predominantly of medium and high intensity, and the more formal ones are mostly low intensity. These results suggest that the low level of formality and poor organizational capacity of a link helps to increase the intensity with which it occurs, whereas links which, by their nature, require organizational skills and some degree of formality and structuring, tend to occur with less intensity.

Knowledge/technology was mostly transferred (in the cooperation links studied) by "simple transfer", in which informal contacts with academics was very important. It was also interesting to see that the main final results from this group of links were related to "advice and technical consultancy (written and non-written)" (87\%). This confirms earlier studies [18-22], stressing that the university contribution to developing firms' entrepreneurial activities has more to do with supplying information to complement their internal technological efforts, rather than with achieving a market-ready product/service innovation. Universities thus do more to help firms by developing their traditional activities, via training human resources and increasing their stock of knowledge by aiding independent research. It is thus only marginally relevant to firms' innovative activity.
The study reveals also that certain characteristics of incubators and firms influence the establishing U-I interactions. First, the results of this study confirmed the results of the empirical studies mentioned in Section 2, i.e. those indicating the determining factors for U-I cooperation links, the "sector of economic activity" [18, 19], "firm size/number of employees" [24-27] and "R\&D activities" $[20,3,28]$. Second, this research also identified two other factors, such as the "statutory situation of the incubator" and "firm origin", which affect the existence of cooperation links. However, it was expectable that these factors were also relevant in other contexts, due to the increasing number of the biotechnology firms to which these factors relate to.

Lastly, we analysed the importance of the incubator as a knowledge/technology transfer mechanism. This study has found that the "economic sector", "size/number of employees", and existence of "R\&D activities" of firms under incubation influenced the decision to locate in incubators, and these characteristics were thus dependent on certain incubator characteristics, such as "statutory situation", the "university's shareholding in its capital" and its "sources of funding".

Regarding the policy implications for the universities while conducting and inciting the knowledge/technology transfer and the business incubation, and for the firms and society while supporting and facilitating the mechanisms creating new start-ups, it is possible to deduce five concrete policy measures in order to overcome the existing gap between the university and the firms relations. They assume the university, although their traditional mission of education and research, one third role as entrepreneur, that it cares to value economically the result of its $R \& D$. Those measures are the following: 1-economic exploration by the university of its R\&D results; 2-definition of innovation policies of the university; 3-creation of an interface inside the university and of an incubator on the outside; 4-creation of a network for innovation; and 5-development of concrete actions to motivate the researchers.

These five practical implications mean concrete measures to facilitate the interaction between the university and the firms, the leading role of the whole knowledge/technology transfer process belonging to the academic institution and which cannot be passed on nor transferred, or else the whole process might be compromised. The business incubator is only the means and the mechanism to nurture start-ups and increase knowledge/technology transfer.

The conclusions and observations support the ideas presented in the literature review. Universities and firms are 
separate social actors, with specific goals and purposes. They also engage in R\&D, with varying goals, results and remunerative procedures. These differences give them specific comparative advantages, and also define their individual fields of action. Within a firm, innovation is a highly complex process, and $R \& D$ is just one input that a firm can utilize in its search for technical solutions or in the implementation of an innovative product or process.

\section{APPENDIX A}

\section{Interview Script 1: For Incubators Managers}

\section{I - INCUBATOR'S IDENTIFICATION AND ITS}

\section{CHARACTERISTICS}

1- What is the name of the Incubator? When was it founded (and/or start - up date)?

2- What is the legal form of the incubator?

- Private non - profit Institution:

- Private limited company:

- Public limited company:

- Other:

3- What is the statutory/dependence of the incubator?

- University Incubator:

- Incubator incorporated within a S\&T Park:

- Incubator incorporated within a Technology Park:

- Incubator based in a Technology Park:

- Business Innovation Centers (BIC):

- Independent Incubator:

- Other:

4- Shareholding in incubator capital (number and percentage)?

5- Which university is the incubator's promoting entity and/or associated entity?

6- Has your incubator any sector orientation defined in the statutes? No:

- Yes:___ Which one?

- Services enterprise incubator:

- Commercial enterprise incubator:

- Technology based business incubator:

- Other:

\section{II - INCUBATOR MANAGEMENT}

7- Does Management have an annual plan of activities? Is there a strategic plan or any other plan of similar nature?

8- What are the incubator's funding sources?

- Rent income:

- Income from services rendered:

- "Business angels" investments:

- Venture Capital:

- Community funding:

- University funding:

- Local, regional and central government grants:

- Other:

III - SERVICES AND ACTIVITIES PROVIDED BY THE INCUBATOR

9- What are the services the incubator provides the based enterprises with:
1- Basic services

- Physical Infrastructures:

- Cleaning:

- Telecoms:

- Other:

2- Technical Services

- Access to University R\&D:

- Technical consultancy:

- Other:

3- Management services

- Accounting/Financial:

- General management:

- Sales/Marketing:

- Other:

4- Strategic services

- Access to information on funding sources:

- Access to legislation:

- Support in bank negotiations:

- Technical training of Human Resources:

- Support in institutional relations and agreements between firms:

- Other:

\section{IV - COOPERATION ASSESSMENT BETWEEN} UNIVERSITY - FIRM

10 - What are the reasons leading the incubator to support and motivate firms to establish cooperation links with the university?

11 - How do you evaluate the present cooperation between the university and the based firms? What are the reasons for the non - existence of links in some of the firms?

12 - Regarding the firms with cooperation links, do you think these links are relevant to their success in the market?

- Yes: __ Why?

- No: ___ Why?

13 - Would it be possible to give the present list of firms based in the incubator and their contacts? Which firms have had cooperation links with the university?

14 - Would it be possible to give the statutes and regulations of the incubator and the last three management and business reports?

\section{APPENDIX B}

Interview Script 2: For Directors of Firms Based in the Incubators

I - GENERAL IDENTIFICATION OF THE FIRM

1- State the name of the firm and year of foundation.

II - FIRM'S CHARACTERISTICS

2- Firm's origin:

- University Spin - off firm:

- Other firm's spin - off:

- New firm:

- Already existing firm:

- Subsidiary of already existing firm:

- Other: 
3- Sector of economic activity:

1- Information and Communications Technology ICT (Including: 1 - Communications; 2 Computer Hardware; 3 - Computer Software and 4 - Electronics):

2- Biotechnology and Health (Including: 5 Medical and Health care products and services and 6 - Genetic engineering and molecular biology):

3- Other sectors (Including 7 - Energy; 8 Consumer products; 9 - Industrial products and 10 - Other sectors):

4- How long has your firm been in incubation?

- Less than 1 year:

- 1 to 2 years:

- 2 to 3 years:

- More than 3 years:

5- Legal form of the firm:

- $\quad$ Private limited company:

- Public limited company:

- Sole proprietorship:

- Other:

6- $\quad$ Firm size (no. employees):

- Up to 3 employees:

- 4 to 10 employees:

- 11 to 15 employees:

- $\quad 16$ to 25 employees:

- 26 to 50 employees:

- More than 50 employees:

7- Main activity of the firm:

- R\&D:

- Software development:

- Hardware development:

- Prototype design and construction:

- Production and manufacturing:

- Consultancy:

- Testing and laboratory analysis:

- Sales and Distribution:

- Other:

8- R\&D activities:

- No R\&D:

- Full - time R\&D:

- Part - time R\&D:

9- Type of R\&D activity:

- Basic research:

- Applied research:

- Experimental development in:

. New product development:

. New process development:

. Improving existing products:

. Improving existing processes:

. New administrative techniques:

Other:

10- Intensity of R\&D activity (no. of employees involved)? (only in full - time R\&D firms)

- Up to 2:

- 3 to 5 :

- 6 to 9:

- More than 10:

\section{III - UNIVERSITY - INDUSTRY COOPERATION}

11- What are the cooperation links between your firm and the university?

A) R\&D and Human Resources links:

1- R\&D contracts:

2- R\&D projects of university - sponsored firms:

3- Firm's access to university R\&D agenda:

4- University personnel allotted full - time to firms:

5- Lecturers and researchers as part - time consultants for firms:

6- Informal contacts with academics:

7- Recruitment of new university graduates:

8- Support for student projects:

9- Training given by university to firm's employees:

10- Other

B) Provision of services links:

1- Firm's access to university information and informatics services:

2- Firm's access to university equipment and laboratory facilities:

3- University's laboratory analyses, design, tests and assessments:

4- Firm as supplier of university goods/services:

C) No links:

5- $\overline{\text { Other: }}$

12- What is the frequency (intensity) of links referred to in the previous question?

- $\quad$ High frequency (1 or more links/week):

- $\quad$ Medium frequency (1 link/month):

- Low frequency (3 links per year or less):

13- Reasons for the non - existence of cooperation links with the university (Only if there are no links at all of any kind):

- $\quad$ Lack of opportunity

- Not included in the firm's mission

- The subject has not been evaluated

- University shows no interest in our project

- $\quad$ R\&D is not a priority for us

- Other reasons

IV - ASSESSING THE LOCALISATION IN THE

NCUBATOR AND THE RELATIONSHIP

WITH THE UNIVERSITY

14- What are the reasons for installing your firm in the incubator?

1- To develop R\&D links with the university:

2- To benefit from the prestige and image of the incubator and the university:

3- To benefit from the prestige and the promoting image: incubator (Science Park, Technology or BIC):

4- To benefit from the rented space and other help:

5- To benefit from technical, management and financial support:

6- To access funding sources: 
7- To benefit from the access to knowledge and contacts in the area:

8- To access national markets:

9- To access international markets:

10- To access contacts with other firms:

11- Other: ___ Which?

IF YOU HAVE CHOSEN NO COOPERATION LINKS IN QUESTION 11, THE INTERVIEW FOLLOWS TO QUESTION 21.

15- What are the final results of cooperation links with the university?

- Product and/or process innovation:

- Improving existing product and/or process:

- Building prototypes of new goods and equipment:

- Training of Human Resources:

- Written and non - written advice and technical consultancy:

- Other results:

16- Main forms of knowledge/technology transfer resulting from cooperation links:

- License agreement after patent registration:

- License agreement:

- Acquisition/Sales:

- Simple transfer:

- Other forms of transfer

17- Benefits to firms after cooperation:

- Chance of acquiring know - how, scientific knowledge, technical expertise:

- Low - cost access to technology:

- Means of obtaining third party funding for research:

- Benefiting from university credibility and R\&D experience:

- Continuous technological updating:

- Training of human resources:

- Other Benefits:

18- Effects of technological benefits with cooperation on the firm:

- Improved profitability:

- Increased market share:

- Increased productivity:

- Improved efficiency of the firm:

- Meeting customers' needs:

- Qualifying human resources:

- Other:

19- How do you rate the results obtained with cooperation links? Was there success or not? Why?

20- In your opinion, what does the university benefit from cooperation?

- Chance of applied research projects:

- Chance of applying scientific knowledge in organizations:

- Means of obtaining R\&D funding:

- Practical training of human resources:

- Other:

21- Do you think that the cooperation between university and industry is beneficial to both parties? Why?

\section{APPENDIX C}

Interview Script 3: For the People Responsible for Defining U - I Cooperation Policy and Strategies in the Universities

1- What are the general policies in your university, regarding cooperation and interaction with the community in general?

2- Regarding the firm incubator, what is the purpose of the involvement of the university in the incubation activity?

3- Is there a strategic reason for the sponsoring of an incubator?

4- What are the main reasons for the university to develop University - Industry cooperation links?

5- What are the reasons and the expectations of your university towards sponsoring and supporting an incubator? (Only for universities with incubators)

6- What measures should the university take to increase involvement of researchers in the cooperation?

7- How does your university understand the mission and objectives of an academic institution in the present context of a global knowledge - based economy?

\section{APPENDIX D}

Factors Motivating Firms to Install Themselves in the Incubator

\begin{tabular}{|l|c|c|}
\hline \multicolumn{1}{|c|}{ Factors } & $\begin{array}{c}\text { No. of Firms } \\
\text { (N=79) }\end{array}$ & \% \\
\hline \hline Benefiting from rental space and other help & 62 & 78,5 \\
\hline $\begin{array}{l}\text { Benefiting from the prestige and image of the firm } \\
\text { promoting the incubator }\end{array}$ & 41 & 51,9 \\
\hline Access to contacts with other firms & 30 & 39,2 \\
\hline $\begin{array}{l}\text { Benefiting from the prestige and image of the } \\
\text { incubator and the university }\end{array}$ & 29 & 36,7 \\
\hline $\begin{array}{l}\text { Benefiting from access to knowledge and contacts } \\
\text { in the area }\end{array}$ & 20 & 25,3 \\
\hline Further development of R\&D with the university & 14 & 17,7 \\
\hline $\begin{array}{l}\text { Benefiting from technical, management } \\
\text { and financial support }\end{array}$ & 12 & 15,2 \\
\hline Access to national markets & 11 & 13,9 \\
\hline Access to international markets & 6 & 7,6 \\
\hline Access to funding sources & 12 & 15,2 \\
\hline Other factors & & 38,0 \\
\hline
\end{tabular}

Reasons for the Non - Existence of U - I Cooperation Links

\begin{tabular}{|l|c|c|}
\hline \multicolumn{1}{|c|}{ Reasons } & $\begin{array}{c}\text { No. of Firms } \\
(\mathbf{N = 3 3 )}\end{array}$ & \% \\
\hline \hline Lack of opportunity & 23 & 69,7 \\
\hline Not included in the firm's mission & 8 & 24,2 \\
\hline The subject has not been evaluated & 16 & 48,5 \\
\hline University shows no interest in our project & 5 & 15,2 \\
\hline R\&D is not a priority for us & 5 & 15,2 \\
\hline Other reasons & 2 & 6,1 \\
\hline
\end{tabular}




\section{REFERENCES}

[1] Lundvall B-A. Eds. National systems of innovation-towards a theory of innovation and interactive learning. London: Pinter 1992.

[2] Nelson R. National innovation systems, a comparative analysis. UK Oxford University Press 1993.

[3] Freeman C. The economics of technical change. Critical survey. Cambridge J Econ 1994; 18: 463-514.

[4] Geisler E, Rubenstein AH. University-Industry Relations: a review of major issues. In: Link and Tassey Eds. Cooperative research: new strategies for competitiveness. NY St. Martin Press: 1989.

[5] Hall BH, Link A, Scott J. Barriers inhibiting industry from partnering with Universities: evidence from the advanced technology program. J Technol Transf 2001; 26: 87-98.

[6] Lööf H, Broström A. Does knowledge diffusion between university and industry increase innovativeness? J Technol Transf 2008; 32: 73-90.

[7] Marques JPC, Caraça JMG. University-industry co-operation: the Coimbra University network of Private non-profit institutions. Sci Public Policy 1998; 25: 343-34.

[8] Santoro MD, Gopalakrishnan S. Relationship dynamics between University research centers and industrial firms: their impact on technology transfer activities. J Technol Transf 2001; 26: 163-71.

[9] Schartinger D, Schibary A, Gassler H. Interactive relations between universities and firms: empirical evidence for Austria. J Technol Transf 2001; 26: 255-68.

[10] Siegel D, Thursby J, Thursby M, Ziedonis A. Organizational issues in university-industry technology transfer: an overview of the symposium issue. J Technol Transf 2001; 26: 5-11.

[11] Vedovelho C. Science Parks and University-Industry interaction: geographical proximity between the agents as a driving force. Technovation 1997; 17: 491-502.

[12] Vedovelho C. Firms' R\&D Activity and Intensity and the University-Enterprise Partnerships. Technol Forecast Soc Change 1998; 58: 215-26.

[13] Arvanitis S, Sydow N, Woerter M. Do specific forms of universityindustry knowledge transfer have different impacts on the performance of private enterprises? An empirical analysis based on Swiss firm data. J Technol Transf 2008; 33: 504-33.

[14] Ponomariov B. Effects of university characteristics on scientists' interactions with the private sector: an exploratory assessment. J Technol Transf 2008; 33: 485-503.

[15] Etzkowitz H, Leydesdorff L. The future location of research: a triple helix of university-industry-government relations. EAAST Rev 1996; 15: 20-5.

[16] Etzkowitz H, Webster A, Gebhardt C, Terra B. The future of the university and the university of the future evolution of ivory tower to entrepreneurial paradigm. Res Policy 2000; 29: 313-30.

[17] Etzkowitz H. Incubation of incubators: innovation as a triple helix of university-industry-government networks. Sci Public Policy 2002; 29: 115-28

[18] Faulkner W, Senker J. Making sense of diversity: public-private sector research linkage in three technologies. Res Policy 1994; 23 : 673-95.

[19] Faulkner W, Senker J. Knowledge frontiers. Oxford: Clarendon Press 1995.

[20] Grossman JH, Reid PP, Morgan RP. Contributions of academic research to industrial performance in five industry sectors. J Technol Transf 2001; 26: 143-52.

[21] Klevorick AK, Levin RC, Nelson RR and Winter SG. On the sources and significance of interindustry differences in technological opportunities. Res Policy 1995; 24: 185-205.

[22] Mansfield E. Academic research and industrial innovation. Res Policy 1991; 20: 1-12.

[23] Marques JPC. As incubadoras de empresas com ligações à Universidade e a cooperação universidade-indústria: o caso de Portugal. Ph.D [dissertation]. Aveiro (Portugal): University of Aveiro 2005.

[24] Corsten H. Technology transfer from universities to small and medium-sized enterprises-an empirical survey from the standpoint of such enterprises. Technovation 1987; 6: 57-68.

[25] Corsten H. Problems with cooperation between universities and enterprises-A omparative study on size of enterprise. Technovation 1987; 6: 295-301.
[26] Deiaco E. New views on innovative Activity and Technological Performance: The Swedish Innovation Survey. Science/Technology/Industry (STI) Review 1992; 11: 35-62.

[27] Santoro MD, Chakrabarti AK. Firm size and technology centrality in industry-university interactions. Res Policy 2002; 31: 1163-80.

[28] Feller I. University-Industry R\&D Relationships. In: Schmandt J, Wilson R, Eds. Growth Policy in the Age of High Technology. Unwin Hyman 1989; pp. 313-43.

[29] Mcdam M, Galbratth B, Mcdam R, Humphreys P. Business Process and networks in University Incubators: A Review and Research Agendas. Technol Anal Strateg Manage 2006; 18: 45172.

[30] Autio E, Laamanan T. Measurement and evaluation of technology transfer: review of technology transfer mechanisms and indicators. Int J Technol Manage 1995; 10: 643-64

[31] Carayannis EG, Zedtwitz M. Von. Architecting gloCal (globallocal), real-virtual incubator networks (G-RVINs) as catalysts and accelerators of entrepreneurship in transitioning and developing economies: lessons learned and best practices from current development and business incubation practices. Technovation 2005; 25: 95-110.

[32] Hackett SM, Dilts DM. Real Options-Driven Theory of Business Incubation. J Technol Transf 2004; 29: 41-54.

[33] Hackett SM, Dilts DM. A systematic review of business incubation research. J Technol Transf 2004; 29: 55-82.

[34] OECD. Technology Incubators: Nurturing small firms. Report of the OECD Workshop on Technology Incubators-25 June. Paris: OECD; 1997.

[35] Aerts K, Matthyssens P, Vandenbempt K. Critical role and screening practices of European business incubators. Technovation 2007; 27: 254-67.

[36] Allen D, Bazan E. Value Added Contributions of Pennsylvania's Business Incubators to Tenant Firms and Local Economies. State College, Pa.: Appalachian Regional Commission and Pennsylvania Department of Commerce; 1990.

[37] Campbell C, Berge D, Janus J, Olsen K. Change Agents in the New Economy: Report on Business Incubation and economic Development. Minneapolis, Minnesota: University of Minnesota; 1988.

[38] Colombo MG, Delnastro M. How effective are technology incubators? evidence from Italy. Res Policy 2002; 31: 1103-22.

[39] Jin C, Jinrong Y, Miao Z. Business incubators in China. Int J Entrepreneurship Innov Manage 2003; 3: 67-77.

[40] Lee KB. The evolutionary process of venture incubation in Korea. Int J Entrepreneurship Innov Manage 2003; 3: 78-86.

[41] Matusiak KB. Business incubators in Poland. Int J Entrepreneurship Innov Manage 2003; 3: 87-98.

[42] Mian S. Assessing the value-added contributions of university technology business incubators to tenant firms. Res Policy 1996, 25: 325-35.

[43] Phillips R. Technology business incubators: How effective as technology transfer mechanisms? Technol Soc 2002; 24: 299-316.

[44] Sofouli E, Vonortas NS. S\&T parks and business Incubators in middle-sized countries: the case of Greece. J Technol Transf 2007; 32: $525-44$.

[45] Tornatzky L, Sherman H, Adkins D. Incubating Technology Businesses: A national benchmarking study. Athens, Ohio: NBIA Publications 2003.

[46] Wiggins J, Gibson D. Overview of US incubators and the case of the Austin technology incubator. Int $J$ Entrepreneurship Innov Manage 2003; 3: 56-66.

[47] Rothaermel F, Thursby M. University-incubator firm knowledge flows: assessing their impact on incubator firm performance. Res Policy 2005; 34: 305-20.

[48] Albert P, Bernasconi M, Gaynor L. Incubation in Evolution: Strategies and Lessons Learned in four countries. Athens, Ohio: NBIA Publications 2004.

[49] Kalis N. Technology Commercialization through new company formation. Athens, Ohio: NBIA Publications 2001.

[50] Lewis D. Does Technology Incubation work? A Critical review of the evidence. Athens, Ohio: NBIA Publications 2002.

[51] Gibb A. Technologietransfer-Universitäten und Klein-und Mittelbetriebe, In Wissens-und Technologietransfer aus deutschen und britischen Hochschulen. Bonn: Bundesminister fur Bildung und Wissenschaft 1986; pp. 42-63. 
(C) Marques et al:; Licensee Bentham Open.

This is an open access article licensed under the terms of the Creative Commons Attribution Non-Commercial License (http://creativecommons.org/licenses/by$\mathrm{nc} / 3.0 /$ ) which permits unrestricted, non-commercial use, distribution and reproduction in any medium, provided the work is properly cited. 